\title{
Quantification, extractability and stability of dissolved domoic acid within marine dissolved organic matter
}

\author{
Jana K. Geuer*, Bernd Krock, Tim Leefmann, Boris P. Koch \\ Alfred Wegener Institute Helmholtz Centre for Polar and Marine Research, Am Handelshafen 12, 27570 Bremerhaven, Germany
}

\begin{abstract}
A B S T R A C T
The widespread diatom Pseudo-nitzschia can produce domoic acid (DA). DA is a compound with well described neurotoxic effects on vertebrates including humans known as amnesic shellfish poisoning (ASP) syndrome. It has also been suggested to serve as an organic ligand that binds to iron and copper. By binding these trace elements, DA may increase their solubility and bioavailability. In order to serve this function, DA has to be excreted and reabsorbed by the cells. Only few records of dissolved domoic acid (dDA) concentrations in the ocean exist. To accomplish quantification by ultra performance liquid chromatography (UPLC), samples have to be pre-concentrated and desalted using solid-phase extraction, a procedure commonly applied for dissolved organic matter. Our major goals were to quantify dDA in a basin-wide assessment in the East Atlantic Ocean, to determine extraction efficiencies for complexed and uncomplexed dDA, and to assess whether domoic acid is represented by its molecular formula in direct-infusion high resolution mass spectrometry. Our results showed that dDA was extracted almost quantitatively and occurred ubiquitously in the ocean surface but also in deeper (and older) water, indicating surprisingly high stability in seawater. The maximum concentration measured was $173 \mathrm{pmol} \mathrm{L}^{-1}$ and the average molar dDA carbon yield was $7.7 \mathrm{ppm}$. Both carbon yield and dDA concentration decreased with increasing water depth. Providing quantification of ADA in the water column, we seek to improve our understanding of toxic bloom dynamics and the mechanistic understanding of DA production.
\end{abstract}

\section{Introduction}

Domoic acid (DA) is a non-essential amino acid occurring in the ocean (Wright et al., 1989). It was first described in 1958 as a secondary metabolite of the macroalga Chondria armata (Takemoto and Daigo, 1958) and later of other red algae species (Jiang et al., 2014). Almost 30 years after its discovery, DA regained attention when it was identified as the causative compound of a shellfish poisoning incident that was prompted by the consumption of blue mussels (Mytilus edulis) in Prince Edward Island, Canada, in 1987. Affected people showed symptoms such as vomiting, diarrhoea, confusion, disorientation, memory loss, coma and death (Quilliam and Wright, 1989; Wright et al., 1989). Due to their neurological symptoms, intoxications caused by seafood contaminated with DA were called amnesic shellfish poisoning (ASP) events (Quilliam and Wright, 1989). After analysing the plankton community at the time of the ASP event, it was suggested that the pennate diatom genus Pseudo-nitzschia pungens $f$. multiseries (later renamed as Pseudo-nitzschia multiseries) was responsible for contaminating the shellfish with DA and was confirmed as a DA-producer (Bates et al., 1998; Bates et al., 1989). In the following years, it became evident that Pseudo-nitzschia species are cosmopolitans and that various species of this genus are capable of DA production (Trainer et al., 2012). If DA enters the food chain in high amounts, its trophic transfer can harm wildlife. High DA levels often occur during Pseudo-nitzschia blooms with high cell densities and DA production. Uptake of toxic Pseudo-nitzschia can lead to an accumulation of elevated DA values in higher trophic level organisms that can be found long after toxic blooms (Lefebvre et al., 2002; Martin et al., 1990). The uptake of high levels of DA via trophic transfer can cause severe neurological dysfunctions and death in mammals (Scholin et al., 2000; Trainer et al., 2000; Wekell et al., 1994).

Dissolved DA (dDA) is furthermore reported to influence other

\footnotetext{
Abbreviations: DOC, dissolved organic carbon; DA, domoic acid; dDA, dissolved domoic acid; ASP, amnesic shellfish poisoning; HNLC, high-nutrients low-chlor-

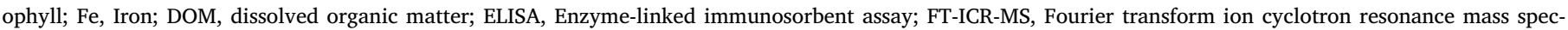

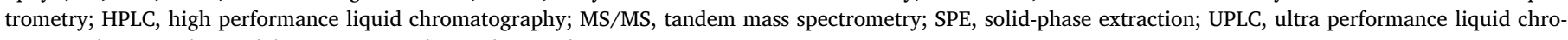
matography; LOD, limit of detection; LOQ, limit of quantification

* Corresponding author.

E-mail addresses: jana.geuer@awi.de (J.K. Geuer), bernd.krock@awi.de (B. Krock), tim.leefmann@awi.de (T. Leefmann), boris.koch@awi.de (B.P. Koch).
} 
phytoplankton and the trophic food web (Van Meerssche and Pinckney, 2017; Bargu et al., 2006; Liu et al., 2007). Cardiac malformation increases in zebrafish embryos when subjected to $3.2 \mathrm{pmol} \mathrm{L}^{-1} \mathrm{dDA}$. At a concentration of $32 \mathrm{pmol} \mathrm{L}^{-1}$ mortality increases and changes in the cardiac development gene expression levels can be observed (Hong et al., 2015). Liu et al. (2007) observed an accumulation of DA in king sea scallops larvae. Growth and survival of the larvae decreased when they were subjected to dDA at a concentration of $96,361 \mathrm{pmol} \mathrm{L}^{-1}$.

In Arctic waters DA-producing Pseudo-nitzschia are common elements of the food chain (Tammilehto et al., 2012). Along the Northeast Atlantic more than ten different Pseudo-nitzschia species occur, especially in the Irish Sea, at the northwest coast of Spain and off the west coast of Africa (Hasle, 2002; Trainer et al., 2012). Reports of DA-producing Pseudo-nitzschia also exist from the Southeast Atlantic at the South African west coast (Pitcher et al., 2014) and the Southwest Atlantic in Argentine coastal waters (Almandoz et al., 2007). Despite the large body of knowledge about the toxicity of DA in mammals, little is known about its ecological function. Even though it is known that DA has an impact on the phytoplankton community and that its production depends on the environmental conditions and the presence of predators (Harðardottir et al., 2015), it is yet to be determined which function DA fulfils for its producers (Prince et al., 2013). Very recently, it has been shown that DA levels increased in Pseudo-nitzschia by exudates of predatory copepods (Tammilehto et al., 2015). Furthermore, escape response levels of copepods decrease under a toxic Pseudo-nitzschia diet (Harðardottir et al., 2018). This strongly suggests that DA production may be involved in an inducible defence mechanism of at least some Pseudo-nitzschia species against grazing. Furthermore, nutrient availability can influence DA production e.g. under phosphate limiting conditions (Lema et al., 2017). DA is capable of chelating iron and copper and may thus participate in iron acquisition or copper detoxification (Rue and Bruland, 2001). Enhanced production of DA was observable in iron fertilization experiments with clearly elevated DA concentrations (Silver et al., 2010; Trick et al., 2010) and in laboratory experiments with elevated DA concentrations under copper stress (Maldonado et al., 2002). In addition, the presence of dDA might improve the acquisition of iron for the producing diatoms (Prince et al., 2013). The observation that, in contrast to other eukaryotic phytoplankton, Pseudo-nitzschia species were frequently found in high-nutrient, low-chlorophyll (HNLC) areas of the world's oceans resulted in the hypothesis that DA-production might be induced by limitation of bio-available iron (Fe) and involved in iron utilization of Pseudo-nitzschia (Wells et al., 2005). Wells et al. (2005) found that under Fe limitation Pseudo-nitzschia actively released DA into the culture medium, which is consistent with its hypothesized function as a compound involved in Fe uptake.

$\mathrm{dDA}$ is also part of the complex pool of marine DOM that plays an important role in the interaction between the geosphere and biosphere (Amon and Benner, 1996; Ludwig et al., 1996). Marine organic ligands represent one group of these interacting molecules within bulk DOM, as they have the capability of complexing trace metals (Ahsanullah and Florence, 1984; Gledhill and van den Berg, 1994; Gordon et al., 2000; Skrabal et al., 2000). Ligands can either help reduce toxic trace metals such as copper (Ahsanullah and Florence, 1984) or mediate the transport of essential trace metals such as iron or zinc (Aristilde et al., 2012; Gledhill and van den Berg, 1994). If DA is released by Pseudo-nitzschia into the marine environment as Fe activator and given the global distribution of Pseudo-nitzschia, dDA should be part of dissolved organic matter (DOM) at least in areas with frequent Pseudo-nitzschia proliferations. Marine DOM constitutes the largest proportion of organic carbon in the ocean (Hansell et al., 2009). The photic zone, depending on site and season, contains highest DOM concentrations, as it is released during primary production (Azam et al., 2011; Fischer et al., 2000). Bulk DOM can be categorised into refractory, semi-labile and labile DOM (Amon and Benner, 1996; Carlson and Ducklow, 1995). Marine microorganisms metabolise labile and semi-labile DOM, which is turned over more rapidly (Kirchman et al., 1991).

Fourier transform ion cyclotron resonance mass spectrometry (FTICR-MS) enables assessing complex organic mixtures (Kujawinski et al., 2002; Stenson et al., 2002) and, due to its high mass resolution and accuracy, allows the assignment of molecular formulas and thus molecular elemental ratios (Koch et al., 2005; Stenson et al., 2003). In combination with other approaches, such as bacterial activity monitoring, the transformation of specific molecular formulas in DOM samples can be tracked with FT-ICR-MS (Kamjunke et al., 2017).

Solid-phase extraction is a common method for DOM extraction, enrichment and desalting. Different sorbents were applied in the past, including e.g. the silica based C18 (Aiken et al., 1979; Kim et al., 2003; Louchouam et al., 2000) and the styrene divinyl benzene polymer (PPL, Agilent; Dittmar et al., 2008; Li et al., 2017). dDA samples were desalted and concentrated with solid-phase extraction using magnetic beads of $\mathrm{CuFe}_{2} \mathrm{O}_{4}$ nanospheres (Zhang et al., 2016), on $\mathrm{C} 18$ cartridges (Wang et al., 2007) and a 2-(trifluoromethyl)acrylic acid resin (Piletska et al., 2008). Desalting is necessary for subsequent quantification using high-performance liquid chromatography coupled to electrospray tandem mass spectrometry (HPLC-MS/MS) (Furey et al., 2001; Piletska et al., 2008; Wang et al., 2007).

Although particulate DA has been frequently measured in marine samples, only few studies covered dDA (Busse et al., 2006; Trainer et al., 2009; Umhau et al., 2018). Previous dDA quantification in seawater was based on a derivatisation procedure and subsequent quantification via HPLC and fluorescence detection (Pocklington et al., 1990). Enzyme-linked immunosorbent assay (ELISA) has also been applied to quantify both particulate and dDA (Trainer et al., 2009; Trainer et al., 2000). A method of sample preparation for dDA $(0.45 \mu \mathrm{m}$ filter pore size) was described by Guannel et al. (2015). Another method for the quantification of dDA in seawater combined filtration and a C18 solid-phase extraction prior to LC-MS quantification (Pan et al., 2001; Trainer et al., 2000; Wang et al., 2007). Few records of marine dDA quantification exist for the North American West Coast and the French coast of the southern North Sea (Delegrange et al., 2018; Trainer et al., 2009, 2000), but none for the Atlantic Ocean.

So far, the quantification of marine $\mathrm{dDA}$ is restricted to smaller regions. In this study, our goal was to (i) determine the extraction efficiency of dDA using PPL solid-phase extraction (ii) quantify the concentration of dDA with a highly sensitive chemical method in seawater on a larger spatial scale in the East Atlantic Ocean, (iii) determine if the molecular formula of DA in high resolution mass spectrometry can represent the substance without chromatographic separation, (iv) determine which proportion of the bulk marine DOC is derived from dDA (carbon yield) and (v) assess the depth profile and stability of dDA.

\section{Methods}

\subsection{Study area and sample processing}

Samples were taken on a transect in the East Atlantic Ocean from $50^{\circ} \mathrm{N}$ to $70^{\circ} \mathrm{S}$ (for details see Koch and Kattner, 2012) Water samples were collected during two cruises (ANTXXV/1 and 2 of RV Polarstern) between November 2008 and January 2009. Surface samples $(2 \mathrm{~m}$ water depth) were taken with a towed fish sampler. Water samples from other depths were collected using Niskin bottles attached to a rosette sampler connected to a CTD. All water samples were filtered through pre-combusted $\mathrm{GF} / \mathrm{F}$ filters (Whatman, $0.7 \mu \mathrm{m}$ nominal pore size; combustion: $450^{\circ} \mathrm{C}, 5 \mathrm{~h}$ ), not exceeding a pressure of $200 \mathrm{mbar}$. For DOC and nutrient analysis, aliquots were taken and stored at $-20^{\circ} \mathrm{C}$ in pre-combusted glass ampoules.

Solid-phase extraction (SPE) was performed as described previously (Flerus et al., 2012). In short, $\sim 5 \mathrm{~L}$ of filtered water were acidified to pH 2 (hydrochloric acid, Suprapur, Merck) and extracted using a precleaned styrene-divinylbenzene polymer cartridge (PPL, $1 \mathrm{~g}$, Mega Bond Elut, Varian). After extraction, cartridges were dried and eluted with 
$5 \mathrm{~mL}$ of methanol (LiChrosolv, Merck), equivalent to an enrichment factor of $\sim 1000$. Extracted samples were stored in pre-combusted glass ampules at $-20^{\circ} \mathrm{C}$ to prevent esterification (Flerus et al., 2011).

\subsection{Assessment of domoic acid extraction yield}

The extraction efficiency of dDA was determined for the uncomplexed and the complexed form (DA-iron complex). Sodium chloride (Fisher Chemical) was pre-combusted $\left(500{ }^{\circ} \mathrm{C}\right.$ for $6 \mathrm{~h}$ ) to remove organic material and then dissolved in $500 \mathrm{~mL}$ ultrapure water (Milli-Q, Merck) to a final concentration of $35 \mathrm{~g} \mathrm{~L}^{-1}$. This salt solution was used as reference. For uncomplexed samples, pure DA (Calbiochem, Merck Group) was added to obtain a final concentration of $2 \mu \mathrm{g} \mathrm{L}^{-1}\left(6.4 \mathrm{nmol} \mathrm{L}^{-1}\right)$. In an additional treatment, iron chloride (Fisher Chemical) was added at a final iron concentration of $17.4 \mu \mathrm{g} \mathrm{L}^{-1}\left(64 \mathrm{nmol} \mathrm{L}^{-1}\right)$ to obtain the complexed form of DA. Iron

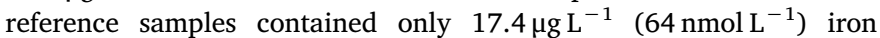
without DA. Prior to extraction, cartridges were conditioned with $6 \mathrm{~mL}$ methanol, followed by $6 \mathrm{~mL}$ ultrapure water acidified to $\mathrm{pH} 2$. All treatments were acidified to $\mathrm{pH} 2$ (hydrochloric acid; Suprapur, Merck) and concentrated by SPE ( $200 \mathrm{mg}$ PPL, Bond Elut, Agilent). The acidified samples were loaded onto the conditioned cartridges at a flow rate $\leq 40 \mathrm{~mL} \mathrm{~min}^{-1}$. After loading, remaining salts were washed off the cartridges with acidified ultrapure water. The cartridges were dried under a nitrogen stream. Elution was performed with $1 \mathrm{~mL}$ methanol (LiChrosolv, Merck). The exact volume of eluates was determined by weighing. Each treatment preparation and extraction was performed in triplicate.

\subsection{Data evaluation}

Quantification of dissolved organic carbon (DOC) and its radiocarbon age as well as molecular characterization by Fourier transform ion cyclotron resonance mass spectrometry (FT-ICR-MS) was performed as described previously (Flerus et al., 2012; Ksionzek et al., 2016).

\subsection{Separation and quantification of dissolved domoic acid}

Quantification of dDA was performed using ultra performance liquid chromatography (UPLC, ACQUITY, Waters) coupled to triple quadrupole mass spectrometry (MS/MS, Xevo TQ-S, Waters). Separation was performed on a BEH C18 column $(2.1 \times 50 \mathrm{~mm}, 1.7 \mu \mathrm{m}$, ACQUITY, Waters) and a pre-column (BEH C18, $1.7 \mu \mathrm{m}$, VanGuard ${ }^{\mathrm{TM}}$, Waters) at a column temperature of $35^{\circ} \mathrm{C}$. Mobile phase A consisted of an aqueous formate buffer ( $40 \mathrm{mM}, \mathrm{pH} 5.8$, ammonium formate, Riedelde Haën; formic acid, Merck), mobile phase B was acetonitrile (LiChrosolv, Merck). Run time was $4.5 \mathrm{~min}$ at a flow rate of $0.6 \mathrm{~mL} \mathrm{~min}^{-1}$. A gradient was run for $3.8 \mathrm{~min}$ from 1 to $99 \%$ B followed by an isocratic step for $0.2 \mathrm{~min}$. In a linear gradient for $0.3 \mathrm{~min}$ eluents were returned to initial conditions and the column was equilibrated for $0.2 \mathrm{~min}$.

The samples were subsequently analysed by UPLC-MS/MS with electrospray ionisation switching between positive and negative mode. Positive ionisation was used to obtain high intensity signals for quantification, while negative ionisation served as quality control. Cone voltage was $30 \mathrm{~V}$ for positive and $-30 \mathrm{~V}$ for negative ionisation, collision energy was $16 \mathrm{~V}$ for positive and $20 \mathrm{~V}$ for negative ionisation, respectively. Mass transitions that were used for the detection of DA were $m / z 312>266$ and $312>193$ in positive mode and $\mathrm{m} / \mathrm{z}$ $310>222$ and $m / z 310>160$ in negative mode.

The dDA concentration was measured in the solid-phase extracts. Due to the complex matrix, the mass concentration of dDA in one extract was determined using standard addition (added concentrations: $0.25,1,510,15,50,100 \mu \mathrm{g} \mathrm{L}^{-1}$ ). dDA concentrations in the remaining extracts were assessed via a one-point calibration. From the extract concentration of $\mathrm{dDA}\left(\mathrm{pg} \mathrm{L}^{-1}\right)$ its molar concentration in the original water samples $[\mathrm{dDA}]\left(\mathrm{pmol} \mathrm{L}^{-1}\right)$ was calculated as follows

$[d D A]=\frac{\frac{[d D A]_{\text {extract }}}{\text { enrichment factor }} \cdot M_{D A}}{0.91}$

where $[\mathrm{dDA}]_{\text {extract }}$ is the concentration of $\mathrm{dDA}\left(\mathrm{pg} \mathrm{L}^{-1}\right)$ in the extract, $\mathrm{M}_{\mathrm{DA}}$ is the molar mass of DA ( $311.33 \mathrm{~g} \mathrm{~mol}^{-1}$ ), enrichment factor is the factor by which a seawater sample was concentrated during SPE $(\sim 1000)$ and 0.91 is the average DA extraction efficiency based on the SPE method applied (see below).

DA carbon yield was calculated according to Eq. (2):

Domoic acid carbon yield $(\mathrm{ppm})=\frac{[d D A] \cdot 15}{[D O C]} \cdot 10^{6}$

where $[\mathrm{DOC}]$ and $[\mathrm{dDA}]$ are the DOC and $\mathrm{DDA}$ concentrations in original seawater, respectively, and 15 is the number of carbon atoms in a DA molecule.

The limits of detection and quantification (LOD and LOQ, respectively) for seawater extracts were assessed via standard addition. Different concentrations of DA were added to a sample in which no dDA was detected. A total of 10 different DA concentrations $(0.1,0.25,0.5$, 1 , 2.5, 5, 10, 50, 100, $1000 \mu_{\mathrm{g} \mathrm{L}}^{-1}$ ) were measured 10 times. Calculations of LOD and LOQ were based on the standard deviation of response and the slope, based on a calibration curve. The limit of detection was defined as

$L O D=\frac{3.3 \cdot \sigma}{\text { slope }}$

where $\sigma$ was the standard deviation of y-intercepts of the linear regression (concentrations $0,0.1,0.25,0.5,1,2.5,5 \mu \mathrm{g} \mathrm{L}^{-1}$ ) close to the LOD and slope was the average slope of a calibration curve with all measured concentrations $(n=10)$. Limit of quantification was calculated analogously using the following formula:

$L O Q=\frac{10 \cdot \sigma}{\text { slope }}$

Due to the matrix underlying the DA peak, other methods to evaluate LOD and LOQ such as using blank deviation or signal-to-noise were inapplicable. Thus, a deep-water sample from the Southern Ocean showing no quantifiable signal at the target mass transition having an assumable very small concentration was picked for the determination of LOQ and LOD. For the method used, LOD was $3 \mu \mathrm{g} \mathrm{L} \mathrm{L}^{-1}$ and LOQ was $8 \mu \mathrm{g} \mathrm{L}^{-1}$, equivalent to an LOD of $\sim 10 \mathrm{pmol} \mathrm{dDA} \mathrm{L}{ }^{-1}$ and LOQ of $\sim 26 \mathrm{pmol} \mathrm{dDA} \mathrm{L}^{-1}$, considering the enrichment factor of $\sim 1000$ for solid-phase extraction. The dataset of this study is available online on the PANGAEA ${ }^{\mathrm{TM}}$ database (https://doi.pangaea.de/10.1594/ PANGAEA.896584).

\subsection{Carbon-weighted relative summed peak intensity in FT-ICR-MS}

To compare the DA carbon yield determined by MS/MS with relative peak intensities obtained by FT-ICR-MS, we calculated carbonweighted relative summed peak intensities (Cw.r.s.i) according to Eq. (5):

Cw.r.s. $i=\frac{r . i_{\cdot D A} \cdot C_{D A}}{\sum r . i_{\text {all }} \cdot C_{\text {all }}}$

where r.i. is the respective relative intensity of either DA or all formulae in the sample and $\mathrm{C}$ is the respective number of carbon atoms.

\subsection{Statistical analysis and sample distinction}

All samples were assigned to two groups: the first group consisted of samples from the epipelagic zone ( $\leq 200 \mathrm{~m}$ water depth); the second group of all samples derived from deeper layers. The samples were furthermore grouped into a northern and southern area at a 
longitudinal split at $12^{\circ} \mathrm{S}$ based on bio-optical provinces by Taylor et al. (2011). The authors performed a pigment-based study and bio-optical characterization during the same cruise. They defined bio-optical provinces based on phytoplankton community structure by their bio-optical features with cluster analysis of hyperspectral data and simultaneous pigment analysis. Linear regression models were used to test for correlation between pairwise variables. Differences between group averages were assessed by one-sided Wilcoxon rank sum tests and results were considered significant if the calculated probability was below 0.05 .

\section{Results}

\subsection{Extraction and quantification of dissolved domoic acid}

The extraction efficiency of uncomplexed dDA using PPL cartridges in saline water was $91 \pm 3 \%(n=3)$ and significantly higher $(p<0.05)$ compared to Fe(III)-spiked dDA treatments $(78 \pm 3 \%)$. Only the uncomplexed form of $\mathrm{dDA}$ was quantified in the extracts.

The retention time for DA in the UPLC method used was $0.60 \pm 0.01 \mathrm{~min}(n=43$; Fig. 2a). Different mass transitions were recorded simultaneously. Of the four mass transitions that were measured for pure DA, mass transitions in positive ionisation mode resulted in larger peak areas compared to negative ionisation. Mass transition $m / z 312>266$ in positive mode yielded highest peak areas compared to all other transitions. Channel $\mathrm{m} / \mathrm{z} 312>193$ in positive mode was used as a qualitative check for DA, as were the negative mode mass transitions $m / z 310>222$ and $310>160$.

Mass transition peak areas used for quantification showed a significant linear correlation $(p<0.05)$ with increasing dDA concentration both in water and in dDA-spiked extracts with high coefficients of determination (0.99). Although the base line of the quantification trace showed high noise due to the underlying complex organic matrix, the respective DA peaks were reliably distinguished by manual integration. Furthermore, a standard addition experiment confirmed that methanol extracts spiked with dDA showed a higher response and also a linear ion enhancement compared to dDA in aqueous solution with the same concentrations (Fig. 1).

Since dDA quantification was challenged by a strong background matrix, we performed a standard addition for the sample with the largest DA peak area (station 1043 at $2 \mathrm{~m}$ water depth, Fig. 2a). The procedure yielded a linear regression curve (Fig. 2b) with a high coefficient of determination $\left(\mathrm{R}^{2}=0.99\right)$ and small standard errors for y-intercept $(4 \%)$ and slope $(5 \%, n=10)$. Considering the extraction efficiency of $91 \%$, the concentration of dDA was $173 \mathrm{pmol} \mathrm{L}^{-1}$ in original seawater.

Based on the linear regression and the high coefficient of determination we applied a one-point calibration to calculate the concentrations of all other samples. For our calculation of dDA concentrations in the water column, we accounted for the standard recovery of the uncomplexed molecule (91\%) assuming that the equilibrium in the ocean shifts towards uncomplexed dDA. With this quantification strategy, $\mathrm{dDA}$ was detected $\left(\mathrm{LOD}=10 \mathrm{pmol} \mathrm{L}^{-1}\right)$ in $81 \%$ of all samples analysed $(n=216)$.

3.2. Mass and structure: is domoic acid represented by its molecular formula in high resolution mass spectrometry without chromatographic separation?

Direct infusion FT-ICR-MS-spectra of the DOM extracts on average yielded $2718 \pm 803$ different molecular formulas (excl. isotopologues; Fig. 3a). In negative electrospray ionisation, the $\mathrm{m} / \mathrm{z}$ value of 310.13765 represented the singly charged molecular mass of the neutral formula $\mathrm{C}_{15} \mathrm{H}_{21} \mathrm{NO}_{6}$ that is also the molecular formula of DA (Fig. 3a). The DA standard used for quantification showed the same peak.

The molecular formula $\mathrm{C}_{15} \mathrm{H}_{21} \mathrm{NO}_{6}$ was detected in the DA standard and in all samples measured by FT-ICR-MS ( $n=204$; Fig. 3a) and its respective relative peak magnitude contributed between 0.023 and $0.051 \%$ of the summed peak magnitude in each spectrum. However, there was no correlation of the carbon-weighted relative summed peak intensity of the formula and the DA carbon yield (Fig. 3b).

DA has a molecular ratio of hydrogen to carbon $(\mathrm{H} / \mathrm{C}=1.4)$ and oxygen to carbon $(\mathrm{O} / \mathrm{C}=0.4)$ that is close to the average ratio of all calculated molecular formulas in a PPL-extracted marine DOM sample (average $\mathrm{H} / \mathrm{C}$ ratio: 1.25 , average $\mathrm{O} / \mathrm{C}$ ratio: 0.49 ; Fig. $3 \mathrm{c}$ ). A data base query in the open database PubChem (National Center for Biotechnology Information) was carried out to explore other potential known structures for the formula $\mathrm{C}_{15} \mathrm{H}_{21} \mathrm{NO}_{6}$ and its respective molecular mass. The search (as of December 2017) yielded 1193 known chemical structures for the molecular formula of DA.

\subsection{Distribution of dissolved domoic acid in the Eastern Atlantic}

The distribution of $\mathrm{dDA}$ in the water column differed along the study area. Our highest concentration measured was $173 \mathrm{pmol} \mathrm{L}^{-1}$ in surface water close to the equator (Fig. 4a). The overall average concentration of $\mathrm{dDA}$ was $32 \mathrm{pmol} \mathrm{L}^{-1}$. In general, dDA concentrations were highest at the surface and decreased exponentially with increasing depth (Fig. 4b). Significantly higher dDA concentrations were found in

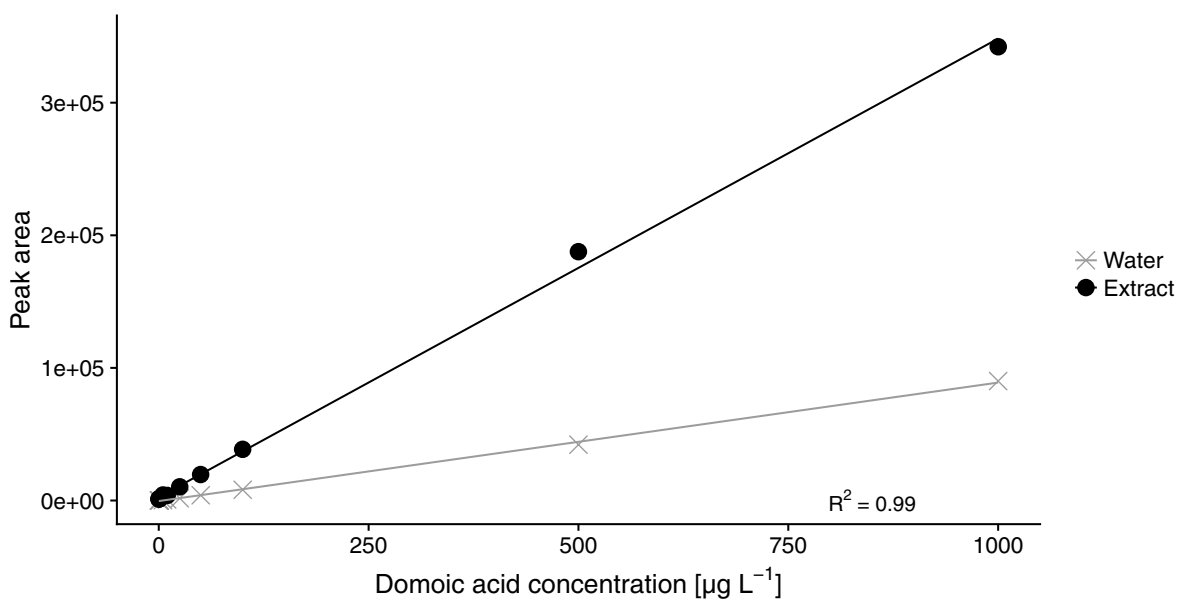

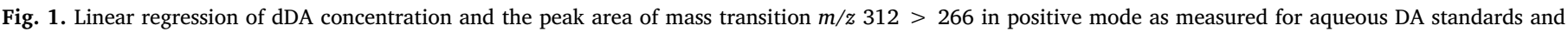
spiked methanol extracts. Grey crosses represent water samples, black dots spiked extracts. For both linear regressions, $\mathrm{R}^{2}$ was 0.99 . 

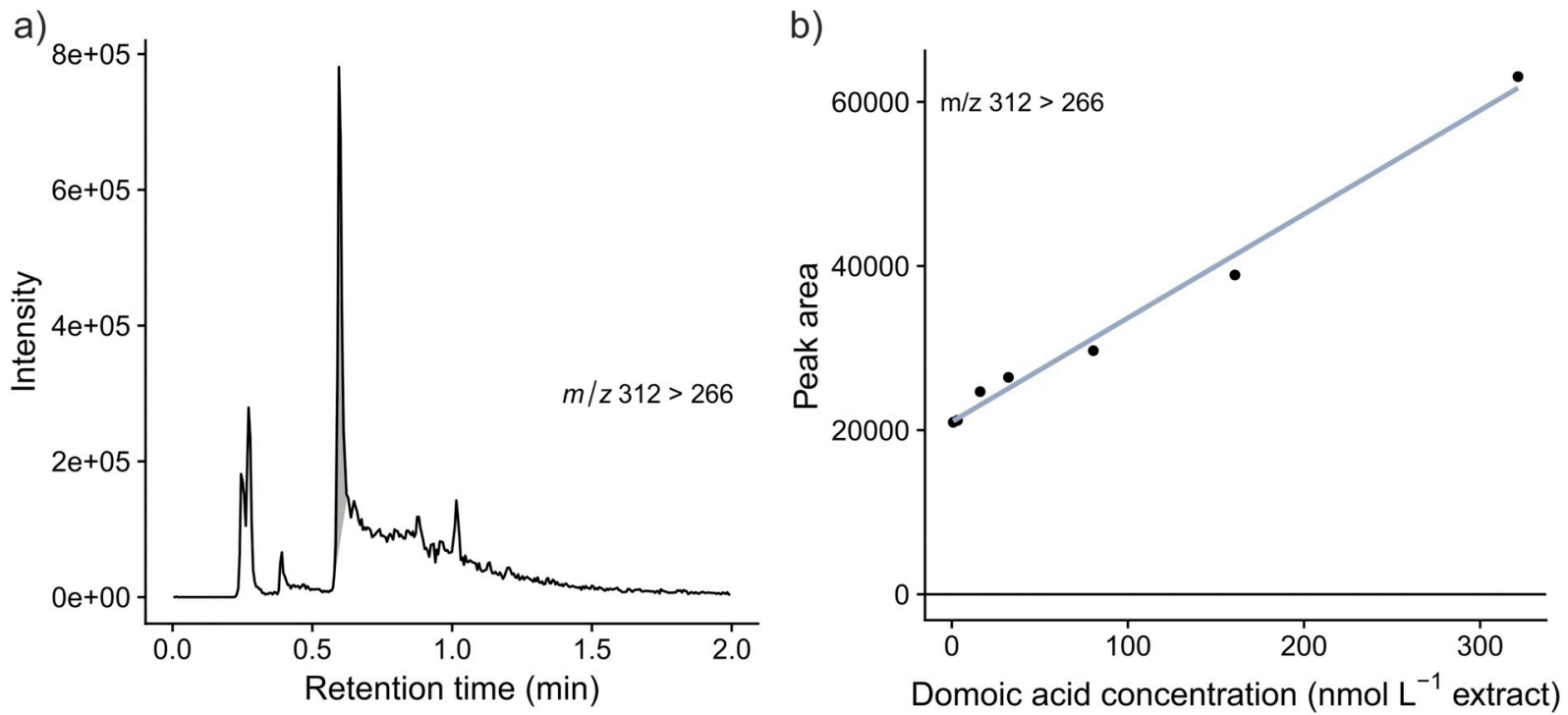

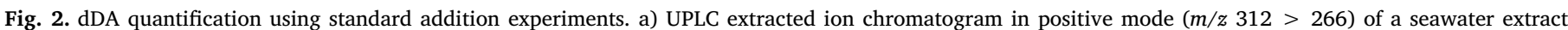

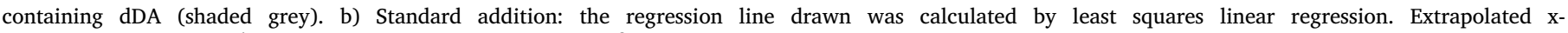
intercept $=167 \mathrm{nmol} \mathrm{L}^{-1}$, y-intercept $=21024$, slope $=1.31, \mathrm{R}^{2}=0.99$.

the epipelagic zone compared to other water depths below $200 \mathrm{~m}$ where concentrations never exceeded $37 \mathrm{pmol} \mathrm{L}^{-1}$. We observed significantly higher dDA concentrations in the northern East Atlantic (North of $12^{\circ} \mathrm{S}$ ) compared to the southern section $(p<0.05$; Fig. $4 a)$.

The average molar contribution of dDA-derived carbon to total DOC (DA carbon yield) was $7.7 \mathrm{ppm}$ and showed the same depth distribution as the dDA concentration: the maximum value was $35 \mathrm{ppm}$ coinciding with the highest dDA concentration (Fig. 4). Similar to dDA concentration, DA carbon yield was significantly higher in the euphotic zone compared to deeper water $(p<0.05)$ and significantly higher in the northern compared to the southern section $(p<0.05)$ (Fig. $4 c$ ). High surface concentrations were observed at the French coast, the northern African coast and in open waters close to the equator.

We carried out multiple linear regressions of dDA concentration with a range of environmental variables that were available from the Eastern Atlantic cruise (Flerus et al., 2012; Lechtenfeld et al., 2014; Taylor et al., 2011). However, no significant correlation with oceanographic parameters or nutrient, amino acid, pigment or iron and copper concentrations could be found.

\section{Discussion}

\subsection{Extraction of dissolved domoic acid from seawater}

An efficient dDA extraction is important, because it allows assessing the contribution of $\mathrm{dDA}$ to bulk marine DOM that is frequently extracted by the same method (Dittmar et al., 2008; Li et al., 2017). The average recovery of dDA in artificial seawater was reproducible, almost quantitative $(91 \pm 3 \%)$, and clearly exceeded the extraction efficiency of bulk marine DOC (42\%; Flerus et al., 2012; Li et al., 2017). Such high dDA recovery is in agreement with results obtained by Wang et al. (2007) who investigated the extractability of dDA in seawater using C18 SPE cartridges and also found a recovery of $>90 \%$. The authors emphasised that DA is highly hydrophilic and that acidification, leading to protonation of carboxyl groups, is essential to achieve good retention on C18 cartridges. Compared to C18, PPL is capable to retain more hydrophilic components, which qualifies PPL for the extraction of dDA as part of the bulk marine DOM.

Differences in the extraction efficiency of complexed and uncomplexed dDA were revealed by the addition of iron chloride to dDA in artificial seawater, which led to a $13 \%$ drop in extraction recovery of
dDA compared to the unspiked dDA treatment. Several competing effects contribute to this change in the recovery: (i) the high ionic strength of the medium, (ii) the impact of sample acidification prior to extraction, and (iii) the stability constant of the Fe-DA complex. Since both treatments were acidified before extraction and the amount of iron chloride added was small compared to the ionic strength of the artificial seawater medium (3.3 ppm change), it is likely that the decrease in recovery was primarily due to the complexation of iron with DA. The extraction was performed at $\mathrm{pH} 2$, where $\mathrm{dDA}$ occurs as a zwitterion and thus nominally neutral (Walter et al., 1992), which is an important precondition for a successful extraction using a moderately nonpolar solid phase. DA metal complex formation is favoured when DA is deprotonated (Fisher et al., 2006). Due to the acidic environment prior to extraction, DA is protonated and thus, the equilibrium shifts to the uncomplexed form of DA. DA is a tricarboxylate amino acid and structurally resembles some terrestrial phytosiderophores, which form tridentate complexes (Rue and Bruland, 2001). Compared to the neutral protonated form of DA, the ionic complex has a higher polarity, which can explain the decrease in extractability. In the spiking experiment, the amount of Fe(III) added (final concentration in water: $64 \mathrm{nmol} \mathrm{L}^{-1}$ ) exceeded the $\mathrm{dDA}$ concentration $\left(6.4 \mathrm{nmol} \mathrm{L}^{-1}\right)$ by a factor of ten, suggesting a high proportion of complexed dDA molecules. Although the decrease of extraction efficiency by $13 \%$ for the complexed dDA was significant, the loss was lower than expected, most likely due to a competitive reaction between complexation with iron and protonation as a result of sample acidification.

\subsection{Quantification of dissolved domoic acid}

The mass transition $m / z 312>266$ in positive mode was chosen for quantification, since it yielded highest peak areas, which is in agreement with previous LC-MS/MS DA quantifications (Scholin et al., 2000; Wang et al., 2007). Since the existing FT-ICR-MS spectra were acquired using negative ionisation (Lechtenfeld et al., 2014), we also applied negative mode mass transitions for quantification and confirmed the presence of dDA in the samples.

We observed high noise in the base line of the quantification trace. Ciminiello et al. (2005) tested a method for the quantification of DA in extracts of tissue. They observed ion suppression for positive and slight ion enhancement for negative ionisation. Comparing calibration curves of DA standards in water and in spiked extracts for the positive mass 


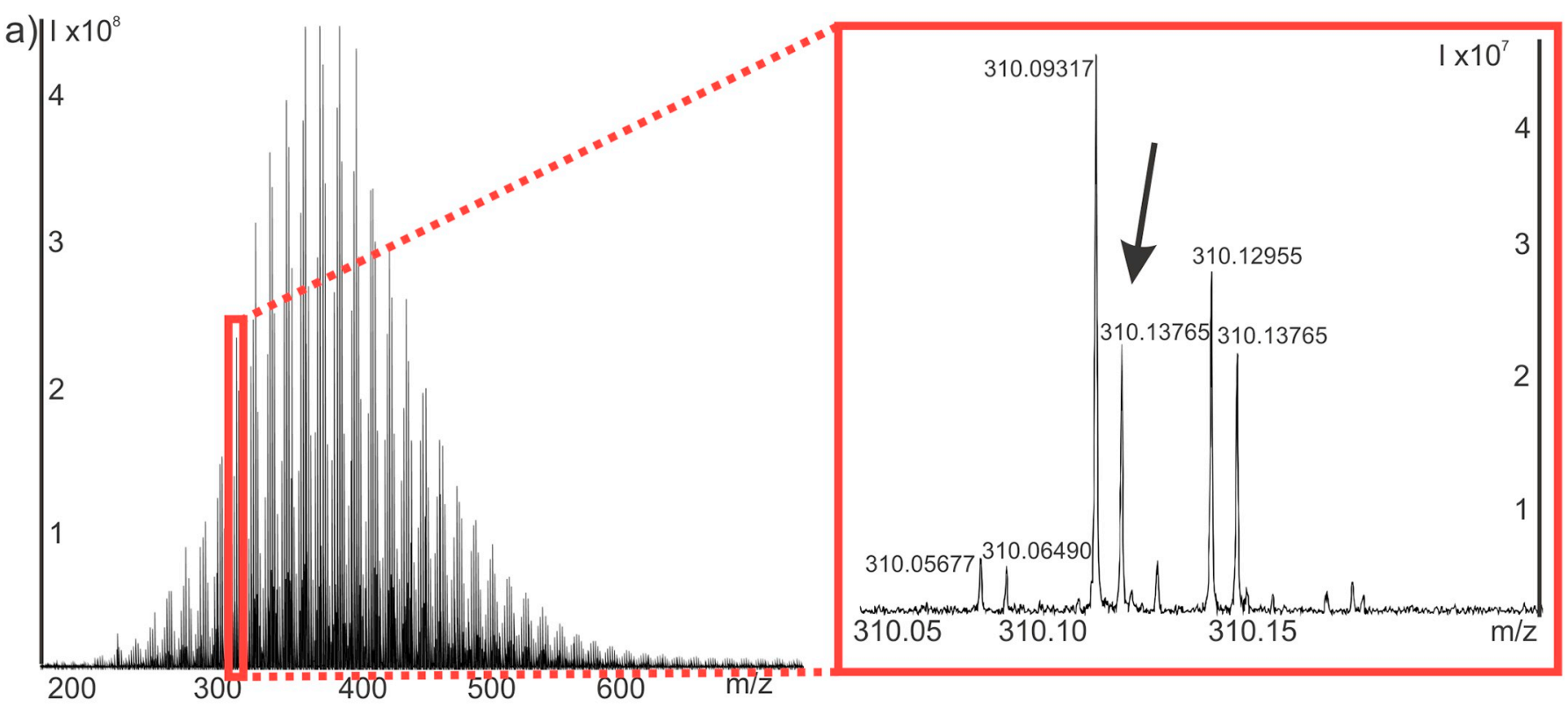

b)

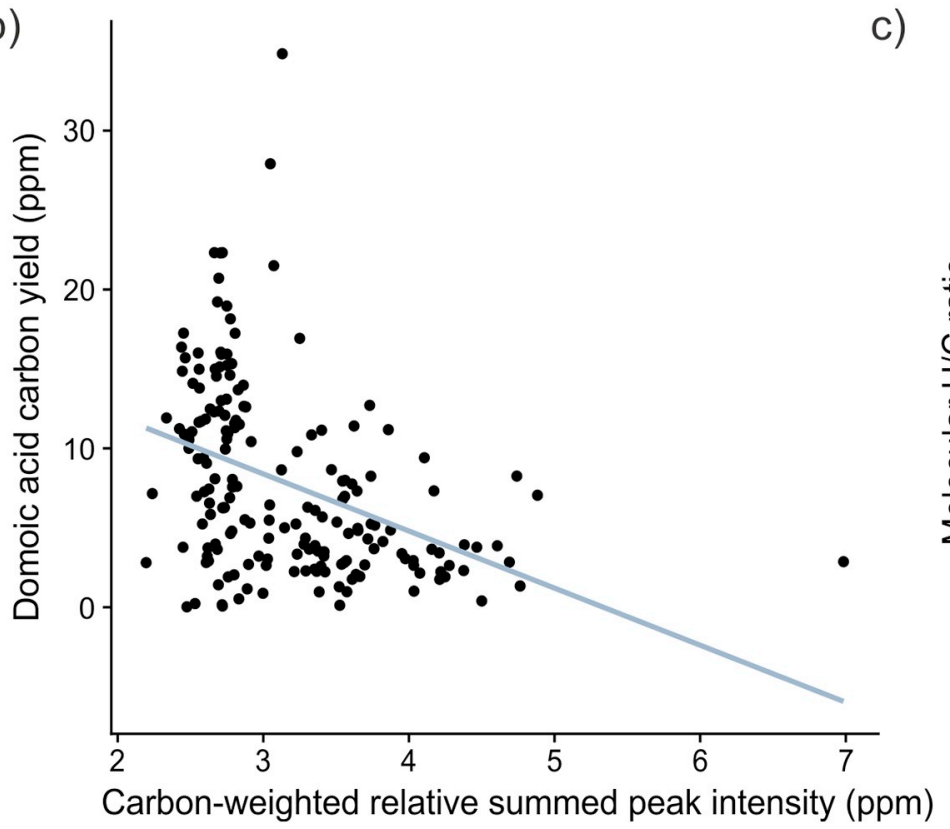

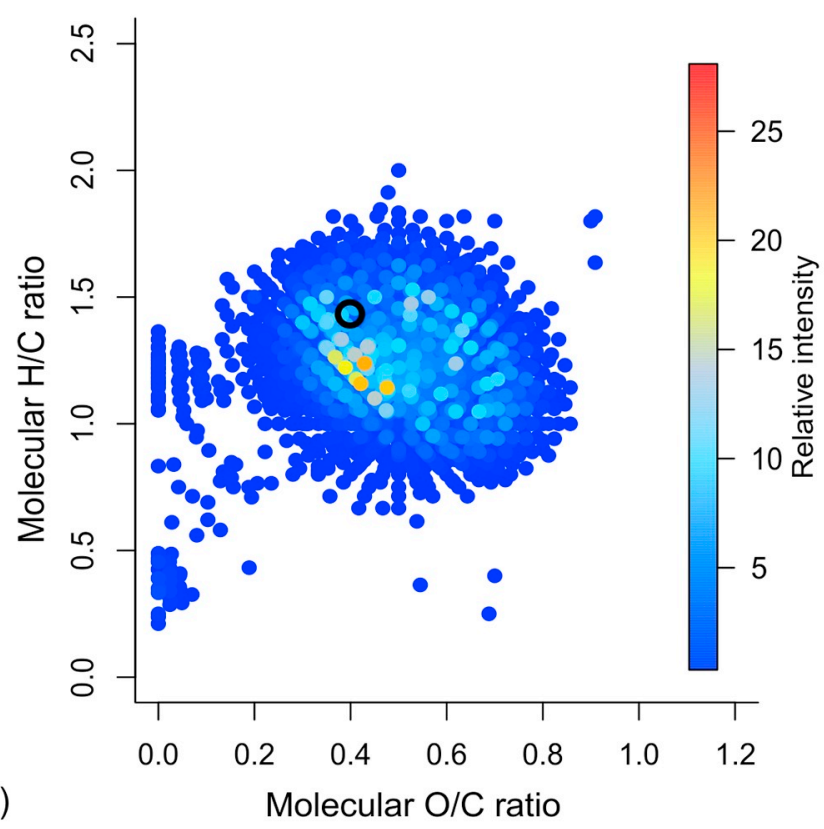

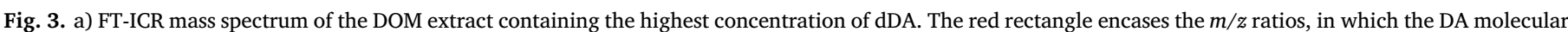

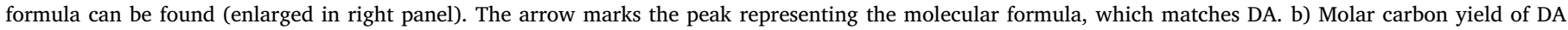

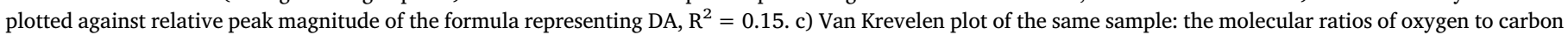

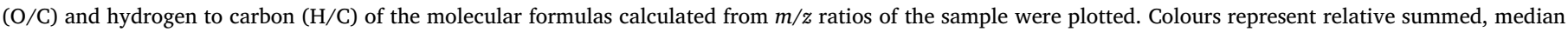

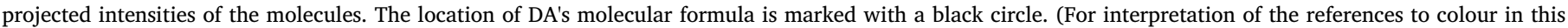
figure legend, the reader is referred to the web version of this article.)

transition revealed that our quantification was subject to a matrix effect. Ciminiello et al. (2005) suggested to use matrix matched standards for quantification to counteract the matrix effects. Thus, we applied a standard addition to quantify the samples. Based on the linear regression and the high coefficient of determination $\left(R^{2}=0.99\right)$, we applied a one-point calibration to calculate the concentration of the other samples.

Using the standard recovery of $91 \%$ to calculate dDA concentrations assumes that the equilibrium in the ocean shifts towards uncomplexed dDA. This is supported by the finding that DA is a weak ligand for iron and copper (Wells et al., 2005) and that its concentration in the Eastern Atlantic (max. $173 \mathrm{pmol} \mathrm{L}^{-1}$ in this study) is well below the concentration of free dissolved iron (Klunder et al., 2011).
We detected dDA in $81 \%$ of our samples implying that the molecule was ubiquitously produced and relatively persistent. It has been previously shown that DA is mainly produced by the marine diatom Pseudo-nitzschia spp. (Bates et al., 1998; Bates et al., 1989), many species of which are cosmopolitans (Casteleyn et al., 2008; Hasle et al., 1996) and capable of producing DA (Hasle, 2002). However, the production of DA is not only dependent on species but on growth conditions and environmental factors (Bates et al., 1998).

Although most of the DA remains in the cell, it is also released into the surrounding seawater, for example under copper stress (Maldonado et al., 2002; Wang et al., 2007). Few previous studies have measured $\mathrm{dDA}$ in seawater, most of which were performed along the West Coast of North America (Trainer et al., 2009; Trick et al., 2018; Umhau et al., 

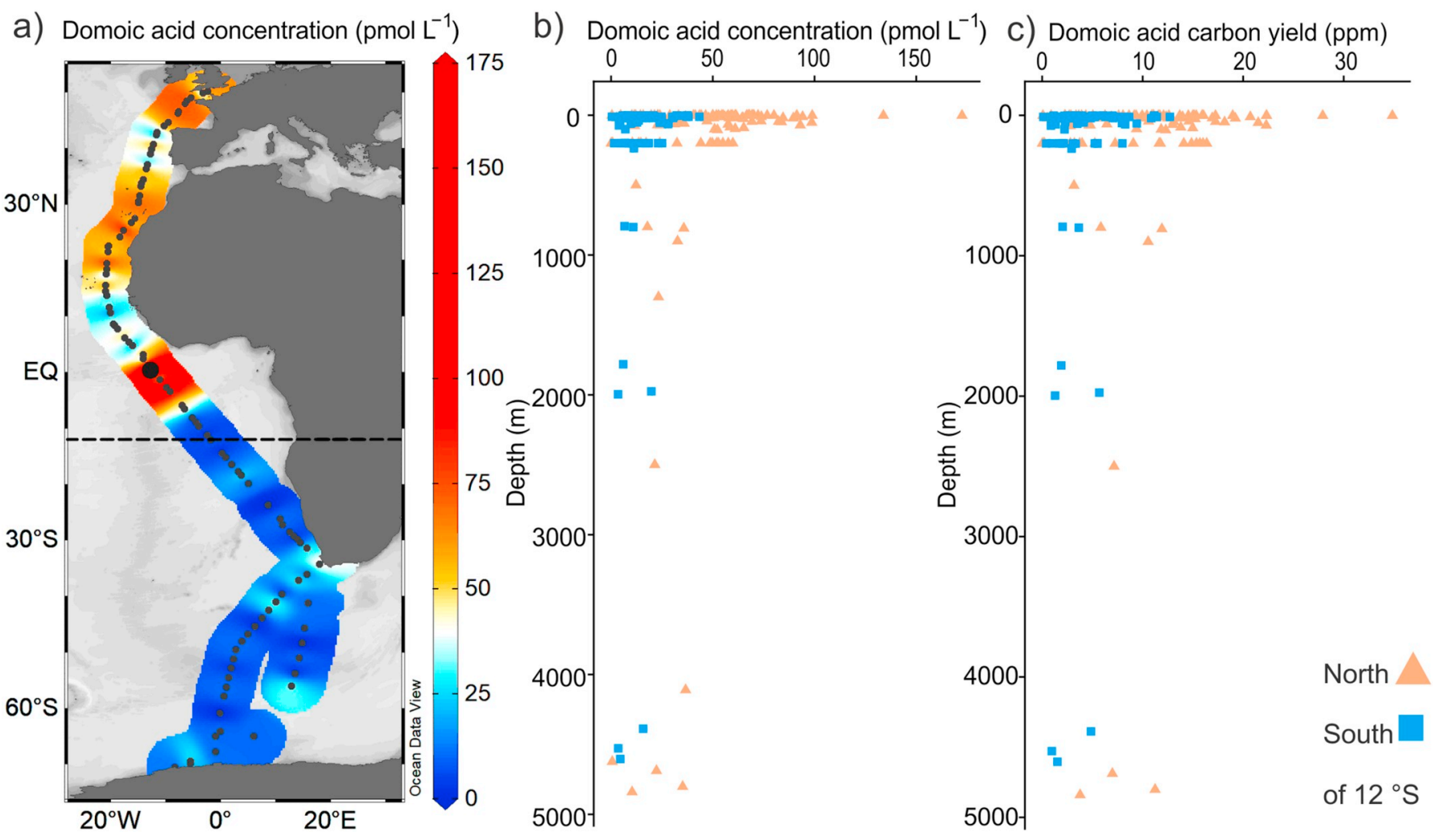

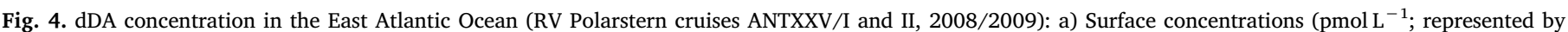

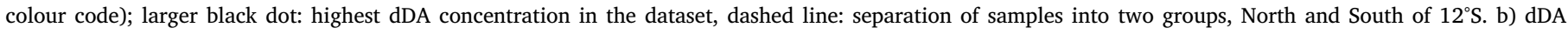

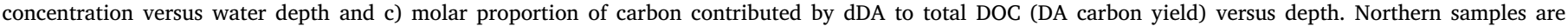

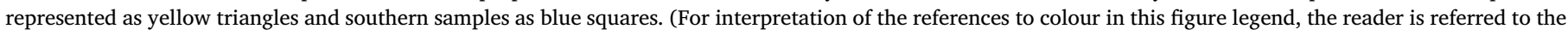
web version of this article.)

2018) or focused on method development (Busse et al., 2006; Guannel et al., 2015; Pocklington et al., 1990).

In the recent past, different methods have been used to quantify dDA in seawater. Wang et al. (2007) quantified dDA by LC-MS with an LOD of $96 \mathrm{pmol} \mathrm{L}^{-1}$, while Trainer et al. (2009) and Guannel et al. (2015) used a direct competitive ELISA for quantification. The LOD for the two methods was $22 \mathrm{pmol} \mathrm{L}^{-1}$ (Trainer et al., 2009) and $32 \mathrm{pmol} \mathrm{L}^{-1}$ (Guannel et al., 2015) compared to an LOD of 10 pmol DA $\mathrm{L}^{-1}$ in our study. Most field studies quantified dDA using ELISA (Delegrange et al., 2018; Trainer et al., 2009; Trick et al., 2018) whereas LC-MS has only been used sporadically for quantification (Trainer et al., 2000; Umhau et al., 2018). The UPLC-MS/MS method developed here allowed fast quantification and a comprehensive spatial assessment of dDA.

Particulate DA (amount of DA in the filter residue for a defined volume of seawater) can reach quite high levels: During a massive coast-wide Pseudo-nitzschia bloom at the North American West Coast high particulate DA values up to $64,241 \mathrm{pmol} \mathrm{L}^{-1}$ were found (McCabe et al., 2016). Smith et al. (2018) also reported up to $86,817 \mathrm{pmol} \mathrm{L}^{-1}$ particulate DA during Pseudo-nitzschia blooms at the Californian coast. Guannel et al. (2015) measured a maximum of $592 \mathrm{pmol} \mathrm{L}^{-1}$ particulate DA in the South Atlantic Ocean during austral spring 2007, exceeding our maximum dDA concentration by a factor of three. Based on the results of Guannel et al. (2015), it was to be expected that the concentrations of dDA measured in this study were well below the value of the particulate phase. Wang et al. (2007) found that the dDA concentration in the medium surrounding the cell was approximately $11 \%$ of the intracellular DA levels. In a time series study in the southern North Sea, dDA contributed around $83 \%$ of the total measured DA (Delegrange et al., 2018). During a toxic bloom of Pseudo-nitzschia, dDA should thus be released into the surrounding water in amounts well quantifiable by the method used in this study.

DA has been suggested to improve trace metal acquisition for its producers (Rue and Bruland, 2001; Prince et al., 2013; Maldonado et al., 2002). Due to its widespread spatial distribution, dDA does not only have the potential to change available trace metal concentrations for Pseudo-nitzschia, but for other protists as well. A negative effect of dDA on the growth of the diatom Skeletonema marinoi likely connected to iron availability could be observed in an experiment (Prince et al., 2013). The release of dDA might also decrease cupric ion concentrations and thereby enhance the growth of co-occuring Eutreptiella spp. in the field (Trick et al., 2018). Additionally, growth inhibition of other phytoplankton with dDA was previously observed at high salinities (Van Meerssche and Pinckney, 2017). Furthermore, dDA can also affect higher trophic level organisms: the survival and growth of king sea scallops larvae has been shown to decrease under dDA exposure of $96,361 \mathrm{pmol} \mathrm{L}^{-1}$ (Liu et al., 2007) and increasing dDA levels can supress krill grazing rates (Bargu et al., 2006). In zebrafish embryos, dDA was shown to disrupt normal cardiac development from concentrations of $3.2 \mathrm{pmol} \mathrm{L}^{-1} \mathrm{dDA}$ and embryo mortality rates increased when subjected to dDA concentrations of $32 \mathrm{pmol} \mathrm{L}^{-1}$ (Hong et al., 2015). Thus, our method of quantifying dDA could serve as useful tool to detect such low concentrations that can already affect the surrounding organisms.

\subsection{Mass and structure: is domoic acid represented by its molecular formula in high resolution mass spectrometry without chromatographic separation?}

The molecular formula of DA is $\mathrm{C}_{15} \mathrm{H}_{21} \mathrm{NO}_{6}$, represented by the deprotonated molecular ion of $310.13765 \mathrm{~m} / \mathrm{z}$. This mass was detected in the negative ionisation FT-ICR mass spectra of each sample with an average relative magnitude of $0.033 \%$ of the summed peak magnitudes. 
DA carries three carboxyl groups and a secondary amine group facilitating ionisation in positive and negative electrospray mode (Ciminiello et al., 2005). Ionisation in general has a large impact on selectivity and oxygenated molecules tend to ionise better in negative mode (Hertkorn et al., 2013; Hertkorn et al., 2008).

Since dDA was almost quantitatively extracted by SPE, it is worthwhile to compare its molecular size, elemental composition, and relative peak magnitude of its mass signal to the peak-magnitude weighted average values of the entire pool of molecular formulas in each DOM sample. Compared to the average $m / z$ ratio of bulk DOM (417 Da) (Flerus et al., 2012), the molecular weight of DA was comparatively small, whereas its molecular ratio $(\mathrm{H} / \mathrm{C}=1.4$ and $\mathrm{O} /$ $\mathrm{C}=0.4$ ) was close to the average ratio of all calculated molecular formulas (average $\mathrm{H} / \mathrm{C}$ ratio: 1.25 , average $\mathrm{O} / \mathrm{C}$ ratio: 0.49 ), which makes DA a generic molecule for marine DOM.

The average composition of marine DOM in our study was $\mathrm{C}_{19.0} \mathrm{H}_{23.8} \mathrm{~N}_{0.6} \mathrm{O}_{9.4}$. Based on an average surface bulk DOC concentration of $64 \mu \mathrm{mol} \mathrm{L}^{-1}$, an average of 19 carbon atoms per molecule and 2438 molecular formulas calculated per surface sample, the average DOM compound could contribute a maximum of $1382 \mathrm{pmol} \mathrm{L}^{-1}$ at the surface. For dDA, the calculated maximum concentration was $173 \mathrm{pmol} \mathrm{L}^{-1}$. This average maximum concentration can be considered as a conservative upper limit because it does not consider structural isomers (isobars). However, our dDA concentration only differs by a factor of ten from the maximum value for a naturally occurring single marine DOM compound.

Comparing dDA carbon yield with the respective carbon weighted summed peak intensities should show if the contribution of dDA could explain the magnitude of the signal of the molecular formula $\mathrm{C}_{15} \mathrm{H}_{21} \mathrm{NO}_{6}$ and if this could be estimated by its carbon yield. Therefore it is worthwhile to explore if the relative peak intensities of the DA mass signal $(310.13765 \mathrm{~m} / \mathrm{z})$ correlate with the dDA carbon yield (Fig. 3a). The lack of correlation demonstrated that the structural diversity that is projected on the molecular ion $310.13765 \mathrm{~m} / \mathrm{z}$ was high and concealed the quantitative contribution of dDA.

Although dDA was almost quantitatively extracted, the peak magnitude of its respective formula is dominated by one or many structural isomers with the same molecular formula that are present in higher concentration and/or ionise more efficiently (Cheng et al., 1995). Structural isomers that can contribute to the DA mass peak signal were not covered by our selective DA quantification method (Hertkorn et al., 2013). However, a query in the PubChem database yielded 1193 known chemical structures for the molecular formula $\mathrm{C}_{15} \mathrm{H}_{21} \mathrm{NO}_{6}$. Most of these compounds are unlikely to occur in marine environments and only some are thus likely to account for the imbalance between DA concentration and peak magnitude. However, the database result demonstrates the potentially high chemical diversity that has an important influence on the relative peak magnitudes and therefore prevents quantitative conclusions about molecular compounds in direct infusion analyses of marine DOM using high-resolution mass spectrometry. This is especially true for larger molecules, since the number of structural isomers increases with molecular mass.

\subsection{Spatial distribution of dissolved domoic acid in the Eastern Atlantic}

On average, we observed higher dDA concentrations in the northern part of our sampling transect. High surface concentrations occurred along the French coast, the northern African coast and in open waters close to the equator. Probable sources of dDA are blooms of toxigenic Pseudo-nitzschia species. Hasle (2002) and Trainer et al. (2012) summarised the global occurrence of toxic Pseudo-nitzschia species and listed reports of different toxic species along the East Atlantic towards South Africa. Several species were observed in the English Channel, the coast of Spain and the North West African coast, where also comparatively high dDA concentrations occurred at the surface (Fig. 4a). North of the English Channel, dDA concentrations were recorded for the year
2012 and varied distinctively between months. In November 2012, dDA concentrations of around $160 \mathrm{pmol} \mathrm{L}^{-1}$ were recorded (Delegrange et al., 2018). The dDA concentrations for the same area in the same month of 2008 measured in our study were around $80 \mathrm{pmol} \mathrm{L}^{-1}$, which is likely due to interannual variability. At least one clade of the species Pseudo-nitzschia pungens and the species Pseudo-nitzschia multiseries have been reported to be cosmopolitan (Casteleyn et al., 2008; Hasle, 2002). Both species have been found in the equatorial West Atlantic (Hasle, 2002; Trainer et al., 2012). Pseudo-nitzschia pungens has been reported to be capable of expressing DA in small levels (e.g. Bates et al., 1998; Rhodes et al., 1996; Trainer et al., 1998), whereas Pseudo-nitzschia multiseries is known as toxic species (e.g. Bates et al., 1998; Bates et al., 1989; Fryxell et al., 1990; Subba Rao et al., 1988) and could potentially contribute to high $\mathrm{dDA}$ concentrations observed close to the equator.

Average dDA concentrations south of $12^{\circ} \mathrm{S}$ were $33 \%$ lower compared to the northern locations. For the southern part of the transect, highest dDA concentrations occurred at the tip of South Africa, where the existence of toxic species and a large richness of Pseudo-nitzschia species in the northern Benguela upwelling zone has been reported (Hasle, 2002; Trainer et al., 2012). This zone is prone to toxigenic Pseudo-nitzschia blooms that can impact offshore organisms (Guannel et al., 2015). Taking into consideration that $11 \%$ to $88 \%$ of the total DA can be released as dDA in the medium surrounding Pseudo-nitzschia (Wang et al., 2007; Pan et al., 2001; Umhau et al., 2018), the maximum dDA concentrations measured in this study could stem from particulate DA levels similar to those detected in toxic blooms (Scholin et al., 2000; Trainer et al., 2000). Despite high chlorophyll concentrations in the Southern Ocean, we found relatively low concentrations of dDA (Fig. 4a). Different areas of the Southern Ocean show great variability in plankton diversity (Almandoz et al., 2008; Hasle, 2002; Trainer et al., 2012). Several Pseudo-nitzschia species have been reported to contribute to local diatom communities (Almandoz et al., 2008; Hegseth and Von Quillfeldt, 2002), however, only P. turgidula showed low toxicity (Rhodes et al., 2013). Potential sources of dDA in the Southern Ocean are thus scarce, which matches low dDA concentrations determined in our study.

Although our cruise took place in austral summer and chlorophyll was high at some stations, there was no correlation between chlorophyll and dDA concentration $\left(\mathrm{R}^{2}=0.007\right)$. Taylor et al. (2011) quantified mean values of marine phytoplankton chlorophyll concentrations during the first part of the same cruise via remote sensing. They found two phytoplankton blooms at $\sim 22^{\circ} \mathrm{N}$ and $\sim 15^{\circ} \mathrm{N}$ and also analysed the phytoplankton composition. Stations with the highest diatom yield were outside of these blooms (Taylor et al., 2011) and our surface $\mathrm{dDa}$ concentrations at diatom-dominated stations were relatively low (between 50 and $100 \mathrm{pmol} \mathrm{L}^{-1}$ ). This can be explained by the fact that Pseudo-nitzschia species were likely not dominant within the blooms (Taylor et al., 2011) and that cells with low DA levels excrete less dDA than highly toxic cells (Wang et al., 2007). Furthermore, blooms of Pseudo-nitzschia do not necessarily have to be associated with high DA concentrations (Smith et al., 1990). It is also possible that the occurrence of toxigenic Pseudo-nitzschia cells and dDA concentration are time-decoupled.

\subsection{Depth profiles and stability of dissolved domoic acid}

dDA concentrations were significantly higher in the epipelagic zone in comparison to water depths below $200 \mathrm{~m}$, which is in accordance with the observation of high concentrations of dDA off the North American West coast (Trainer et al., 2009; Trick et al., 2018). dDA concentrations were generally decreasing with increasing depth, which is likely related to the production by Pseudo-nitzschia at the sea surface and the deep chlorophyll maximum, microbial removal and mixing with deep water below the photic zone (Malviya et al., 2016).

The molar proportion of carbon contributed by dDA to total DOC (DA carbon yield) was decreasing similar to the dDA concentration 
profile (Fig. 4b,c). Bulk DOC concentrations decrease with increasing depth, with the proportion of refractory DOC increasing with depth (Carlson and Ducklow, 1995). The decrease of DA carbon yield with increasing depth implies that $\mathrm{dDA}$ is degraded faster than DOC (Fig. 4c). A potential sink for $\mathrm{dDA}$ at the surface is photo-oxidation. Both DOM and Fe(III) accelerate DA photo oxidation, while the presence of phosphate can slow it down (Fisher et al., 2006). Although dDA is degraded within a few days of sunlight exposure (Bouillon et al., 2006), it is only affected within approximately the upper two meters, thus limiting photo-oxidation as dDA sink (Bouillon et al., 2008). Considering that DA carbon yield decreased with depth in the same pattern as dDA concentration, it is not likely that photodegradation was an important dDA sink in our study.

We also found $\mathrm{dDA}$ in deeper water at lower concentrations, likely due to vertical flux (Scharek et al., 1999) and subsequent release of dDA from phytoplankton cells e.g. by sloppy feeding (Møller et al., 2003). Furthermore, DA is rapidly transported downward by vertical particle flux in coastal waters and many cells that are transported downward stay intact (Sekula-Wood et al., 2009). Particulate DA decreases with increasing depth (Sekula-Wood et al., 2009). This could be explained with degradation but also leaching of dDA, resulting in the pattern we observed in our study (Fig. 4b). Recently, Umhau et al. (2018) measured both particulate and dDA in sediment traps at different depths. Both DA pools were almost equal and both were decreasing with depth while their ratio remained unchanged, confirming dDA as important contributor to total DA levels in the ocean. Overall, the widespread occurrence of dDA even in deep Atlantic water suggests that dDA is relatively resistant to degradation. Previous studies have shown that nitrogen, phosphorus and sulfur containing DOM compounds tend to degrade faster due to selective microbial removal (Hopkinson et al., 2002; Hopkinson and Vallino, 2005; Koch et al., 2014; Ksionzek et al., 2016). Since DA is carbon rich and contains only one nitrogen atom but no phosphorus or sulfur, it should be less attractive for microbial consumption. This is in accordance with the previous finding that only few bacterial strains related to shellfish tissue were capable of degrading DA (Stewart et al., 1998).

We found dDA in up to $5000 \mathrm{~m}$ water depth. dDA accumulation in the surface and export flux require a relatively high stability of DA. Although the toxin can be degraded and is removed from the water column faster than average DOC, a transport downwards in intact Pseudo-nitzschia cells and accumulation in higher trophic levels could still serve as a preservation process for DA (Sekula-Wood et al., 2009; Costa et al., 2005). The DOC in our study showed, in accordance with previous other studies, a high radiocarbon age (Lechtenfeld et al., 2014), implying that substances at depth are relatively resistant to degradation. Carbon derived from dDA contributed to this DOC and might even be stabilized within the complex DOM matrix.

\section{Conclusions}

DA has been studied for decades due to its dual role as a marine toxin and organic iron-binding ligand. Our study shows that dDA is well extractable, quantifiable and ionisable in negative electrospray mode using tandem mass spectrometry. The high recovery rate is an ideal premise for its characterization within the entirety of marine DOM.

The molecular formula that matches DA was identified in our FTICR-MS analyses. Molecular mass, $\mathrm{O} / \mathrm{C}$ and $\mathrm{H} / \mathrm{C}$ ratios are close to the average of this study's DOC, which suggests that dDA is a representative contributor to solid-phase extractable DOM. However, as a result of structural diversity, the relative peak magnitude did not correspond to the DA quantity, emphasizing the limits of structural interpretations of non-targeted, direct infusion analyses of highly complex DOM samples using FT-ICR-MS.

The sensitivity of DA quantification using UPLC-MS/MS was high enough to allow for quantification in most samples of our study area, probably due to the ubiquitous occurrence of its primary producing organisms. Generally, dDA quantification could serve as a useful additional tool to monitor the occurrence of DA apart from the quantification in phytoplankton or the contaminated tissue. The widespread occurrence of dDA, also in deep Atlantic Ocean waters, suggests that DA is relatively resistant to degradation.

Quantification of dDA in the water column, as a consequence of enhanced intracellular DA production, supports our future understanding of toxic bloom dynamics, the role of dDA for its producers and assists the development of approaches to chemically characterize marine DOM.

\section{Acknowledgements}

We sincerely thank Claudia Burau for performing solid-phase extraction tests. We would like to acknowledge the crew and the master of the research vessel Polarstern for their support during the cruises Ant $25 / 1$ and $25 / 2$. We are grateful for the support by Wolfgang Drebing and Thomas Max with domoic acid analysis. We furthermore want to express our thanks to Svenja Hoppe, Claudia Burau and Theresa Grunwald for proofreading.

\section{Funding}

This study was financially supported by the strategy fund of the Alfred Wegener Institute Helmholtz Centre for Polar and Marine Research in the framework of the project "Inorganics in organics: Chemical and biological controls on micronutrient and carbon fluxes in the polar ocean" (Koch; IP76010001). Sampling was possible by the support of the Deutsche Forschungsgemeinschaft (DFG) in the framework of the priority programme "Antarctic Research with comparative investigations in Arctic ice areas" (Grant KO 2164/8-1+2).

\section{References}

Ahsanullah, M., Florence, T.M., 1984. Toxicity of copper to the marine amphipod Allorchestes compressa in the presence of water- and lipid-soluble ligands. Mar. Biol. $84,41-45$.

Aiken, G.R., Thurman, E.M., Malcom, R.L., Walton, H.F., 1979. Comparison of XAD macroporous resins for the concentration of fulvic acid from aqueous solution. Anal. Chem. 51, 1799-1803.

Almandoz, G.O., Ferrario, M.E., Ferreyra, G.A., Schloss, I.R., Esteves, J.L., Paparazzo, F.E., 2007. The genus Pseudo-nitzschia (Bacillariophyceae) in continental shelf waters of Argentina (Southwestern Atlantic Ocean, 38-55 S). Harmful Algae 6, 93-103.

Almandoz, G.O., Ferreyra, G.A., Schloss, I.R., Dogliotti, A.I., Rupolo, V., Paparazzo, F.E., Esteves, J.L., Ferrario, M.E., 2008. Distribution and ecology of Pseudo-nitzschia species (Bacillariophyceae) in surface waters of the Weddell Sea (Antarctica). Polar Biol. 31, 429-442.

Amon, R.M.W., Benner, R., 1996. Bacterial utilization of different size classes of dissolved organic matter. Limnol. Oceanogr. 41, 41-51.

Aristilde, L., Xu, Y., Morel, F.M.M., 2012. Weak organic ligands enhance zinc uptake in marine phytoplankton. Environ. Sci. Technol. 46, 5438-5445.

Azam, F., Jiao, N., Sanders, S., Stone, R., Ogawa, H., Amagai, Y., Koike, I., Kaiser, K. Benner, R., Paulinski, J.D., McCarthy, M., Hedges, J.I., Hatcher, P.G., Worden, A.Z. Aristeguí, J., Duarte, C.M., Agustí, S., Doval, M., Álvarez-Salgado, X.A., Hansell, D.A., 2011. Microbial Carbon Pump in the Ocean. AAAS Science. The American Associeation for the Advancement of Science.

Bargu, S., Lefebvre, K.A., Silver, M.W., 2006. Effect of dissolved domoic acid on the grazing rate of krill Euphausia pacifica. Mar. Ecol. Prog. Ser. 312, 169-175.

Bates, S.S., Bird, C.J., de Freitas, A.S.W., Foxall, R., Gilgan, M., Hanic, L.A., Johnson, G.R., McCulloch, A.W., Odense, P., Pocklington, R., Quilliam, M.A., Sim, P.G., Smith, J.C. Subba Rao, D.V., Todd, E.C.D., Walter, J.A., Wright, J.L.C., 1989. Pennate diatom Nitzschia pungens as the primary source of domoic acid, a toxin in shellfish from eastern Prince Edward Island, Canada. Can. J. Fish. Aquat. Sci. 46, 1203-1215.

Bates, S.S., Garrison, D.L., Horner, R.A., 1998. Bloom dynamics and physiology domoicacid-producing Pseudo-nitzschia species. In: Anderson, D.M., Cembella, A.D., Hallegraeff, G.M. (Eds.), Physiological Ecology Harmful Algal Blooms. Springer Berlag, Heidelberg, pp. 267-292.

Bouillon, R.-C., Knierim, T.L., Kieber, R.J., Skrabal, S.A., Wright, J.L.C., 2006 Photodegradation of the algal toxin domoic acid in natural water matrices. Limnol. Oceanogr. 51, 321-330.

Bouillon, R.-C., Kieber, R.J., Skrabal, S.A., Wright, J.L.C., 2008. Photochemistry and identification of photodegradation products of the marine toxin domoic acid. Mar. Chem. 110, 18-27.

Busse, L.B., Venrick, E.L., Antrobus, R., Miller, P.E., Vigilant, V., Silver, M.W., Mengelt, C., Mydlarz, L., Prezelin, B.B., 2006. Domoic acid in phytoplankton and fish in San 
Diego, CA, USA. Harmful Algae 5, 91-101.

Carlson, C.A., Ducklow, H.W., 1995. Dissolved organic carbon in the upper ocean of the central equatorial Pacific Ocean, 1992: daily and finescale vertical variations. Deep Sea Res. II Top. Stud. Oceanogr. 42, 639-656.

Casteleyn, G., Chepurnov, V.A., Leliaert, F., Mann, D.G., Bates, S.S., Lundholm, N., Rhodes, L., Sabbe, K., Vyverman, W., 2008. Pseudo-nitzschia pungens (Bacillariophyceae): A cosmopolitan diatom species? Harmful Algae 7, 241-257.

Cheng, X., Chen, R., Bruce, J.E., Schwartz, B.L., Anderson, G.A., Hofstadler, S.A., Gale, D.C., Smith, R.D., Gao, J., Sigal, G.B., Mammen, M., Whitesides, G.M., 1995. Using electrospray ionization FTICR mass spectrometry to study competitive binding of inhibitors to carbonic anhydrase. J. Am. Chem. Soc. 117, 8859-8860.

Ciminiello, P., Dell'Aversano, C., Fattorusso, E., Forino, M., Magno, G.S., Tartaglione, L., Quilliam, M.A., Tubaro, A., Poletti, R., 2005. Hydrophilic interaction liquid chromatography/mass spectrometry for determination of domoic acid in Adriatic shellfish. Rapid Commun. Mass Spectrom. 19, 2030-2038.

Costa, P.R., Rosa, R., Duarte-Silva, A., Brotas, V., Sampayo, M.A.M., 2005. Accumulation, transformation and tissue distribution of domoic acid, the amnesic shellfish poisoning toxin, in the common cuttlefish, Sepia officinalis. Aquat. Toxicol. 74, 82-91.

Delegrange, A., Lefebvre, A., Gohin, F., Courcot, L., Vincent, D., 2018. Pseudo-nitzschia sp. diversity and seasonality in the southern North Sea, domoic acid levels and associated phytoplankton communities. Estuar. Coast. Shelf Sci. 214, 194-206.

Dittmar, T., Koch, B.P., Hertkorn, N., Kattner, G., 2008. A simple and efficient method for the solid-phase extraction of dissolved organic matter (SPE-DOM) from seawater. Limnol. Oceanogr. Methods 6, 230-235.

Fischer, G., Ratmeyer, V., Wefer, G., 2000. Organic carbon fluxes in the Atlantic and the Southern Ocean: relationship to primary production compiled from satellite radiometer data. Deep Sea Res. II Top. Stud. Oceanogr. 47, 1961-1997.

Fisher, J.M., Reese, J.G., Pellechia, P.J., Moeller, P.L., Ferry, J.L., 2006. Role of Fe(III), phosphate, dissolved organic matter, and nitrate during the photodegradation of domoic acid in the marine environment. Environ. Sci. Technol. 40, 2200-2205.

Flerus, R., Koch, B.P., Schmitt-Kopplin, P., Witt, M., Kattner, G., 2011. Molecular level investigation of reactions between dissolved organic matter and extraction solvents using FT-ICR MS. Mar. Chem. 124, 100-107.

Flerus, R., Lechtenfeld, O.J., Koch, B.P., McCallister, S.L., Schmitt-Kopplin, P., Benner, R., Kaiser, K., Kattner, G., 2012. A molecular perspective on the ageing of marine dissolved organic matter. Biogeosciences 9, 1935-1955.

Fryxell, G.A., Reap, M.E., Valencic, R.L., 1990. Nitzschia pungens Grunow $f$. multiseries Hasle: observations of a known neurotoxic diatom. Nov. Hedwigia Beih 100 171-188.

Furey, A., Lehane, M., Gillman, M., James, K.J., Fernandez-Puente, P., James, K.J., 2001. Determination of domoic acid in shellfish by liquid chromatography with electrospray ionization and multiple tandem mass spectrometry. J. Chromatogr. A 938, $167-174$.

Gledhill, M., van den Berg, C.M.G., 1994. Determination of complexation of iron(III) with natural organic complexing ligands in seawater using cathodic stripping voltammetry. Mar. Chem. 47, 41-54.

Gordon, A.S., Donat, J.R., Kango, R.A., Dyer, B.J., Stuart, L.M., 2000. Dissolved coppercomplexing ligands in cultures of marine bacteria and estuarine water. Mar. Chem. $70,149-160$.

Guannel, M.L., Haring, D., Twiner, M.J., Wang, Z., Noble, A.E., Lee, P.A., Saito, M.A., Rocap, G., 2015. Toxigenicity and biogeography of the diatom Pseudo-nitzschia across distinct environmental regimes in the South Atlantic Ocean. Mar. Ecol. Prog. Ser. 526, 67-87.

Hansell, D., Carlson, C.A., Repeta, D.J., Schlitzer, R., 2009. Dissolved organic matter in the ocean: a controversy stimulates new insights. Oceanography 22, 202-211.

Harðardottir, S., Pančic, M., Tammilehto, A., Krock, B., Møller, E.F., Nielsen, T.G., Lundholm, N., 2015. Dangerous relations in the Arctic marine food web: interactions between toxin producing Pseudo-nitzschia diatoms and Calanus Copepodites. Mar. Drugs 13, 3809-3835.

Harðardottir, S., Krock, B., Wohlrab, S., John, U., Gissel, T., Lundholm, N., 2018. Can domoic acid affect escape response in copepods? Harmful Algae 79, 50-52.

Hasle, G.R., 2002. Are most of the domoic acid-producing species of the diatom genus Pseudo-nitzschia cosmopolites? Harmful Algae 1, 137-146.

Hasle, G.R., Lange, C.B., Syvertsen, E.E., 1996. A review of Pseudo-nitzschia, with special reference to the Skagerrak, North Atlantic, and adjacent waters. Helgolaender Meeresun. 50, 131-175.

Hegseth, E.N., Von Quillfeldt, C.H., 2002. Low phytoplankton biomass and ice algal blooms in the Weddell Sea during the ice-filled summer of 1997. Antarct. Sci. 14, 231-243.

Hertkorn, N., Frommberger, M., Witt, M., Koch, B.P., Schmitt-Kopplin, P., Perdue, E.M., 2008. Natural organic matter and the event horizon of mass spectrometry. Anal. Chem. 80, 8908-8919.

Hertkorn, N., Harir, M., Koch, B.P., Michalke, B., Schmitt-Kopplin, P., 2013. High-field NMR spectroscopy and FTICR mass spectrometry: powerful discovery tools for the molecular level characterization of marine dissolved organic matter. Biogeosciences $10,1583-1624$.

Hong, Z., Zhang, Y., Zou, Z., Zhu, R., Gao, Y., 2015. Influences of Domoic acid exposure on cardiac development and the expression of cardiovascular relative genes in zebrafish (Daniorerio) embryos. J. Biochem. Mol. Toxicol. 29, 246-260.

Hopkinson, C.S., Vallino, J.J., 2005. Efficient export of carbon to the deep ocean through dissolved organic matter. Nature 433, 715-717.

Hopkinson, C.S., Vallino, J.J., Nolin, A., 2002. Decomposition of dissolved organic matter from the continental margin. Deep Sea Res. II Top. Stud. Oceanogr. 49, 4461-4478.

Jiang, S., Kuwano, K., Ishikawa, N., Yano, M., Takatani, T., Arakawa, O., 2014. Production of domoic acid by laboratory culture of the red alga Chondria armata. Toxicon 92, 1-5.
Kamjunke, N., von Tümpling, W., Hertkorn, N., Harir, M., Schmitt-Kopplin, P., Norf, H., Weitere, M., Herzsprung, P., 2017. A new approach for evaluating transformations of dissolved organic matter (DOM) via high-resolution mass spectrometry and relating it to bacterial activity. Water Res. 123, 513-523.

Kim, S., Kramer, R.W., Hatcher, P.G., 2003. Graphical method for analysis of ultrahighresolution broadband mass spectra of natural organic matter, the van Krevelen diagram. Anal. Chem. 75, 5336-5344.

Kirchman, D.L., Suzuki, Y., Garside, C., Ducklow, H.W., 1991. High turnover rates of dissolved organic carbon during a spring phytoplankton bloom. Lett. Nat. 352, 612-614.

Klunder, M.B., Laan, P., Middag, R., De Baar, H.J.W., van Ooijen, J.C., 2011. Dissolved iron in the Southern Ocean (Atlantic sector). Deep. Res. Part II Top. Stud. Oceanogr. $58,2678-2694$.

Koch, B.P., Kattner, G., 2012. Sources and rapid biogeochemical transformation of dissolved organic matter in the Atlantic surface ocean. Biogeosciences 9, 2597-2602.

Koch, B.P., Witt, M., Engbrodt, R., Dittmar, T., Kattner, G., 2005. Molecular formulae of marine and terrigenous dissolved organic matter detected by electrospray ionization Fourier transform ion cyclotron resonance mass spectrometry. Geochim. Cosmochim. Acta 69, 3299-3308.

Koch, B.P., Kattner, G., Witt, M., Passow, U., 2014. Molecular insights into the microbial formation of marine dissolved organic matter: recalcitrant or labile? Biogeosciences 11, 4173-4190.

Ksionzek, K.B., Lechtenfeld, O.J., McCallister, S.L., Schmitt-Kopplin, P., Geuer, J.K., Geibert, W., Koch, B.P., 2016. Dissolved organic sulfur in the ocean: biogeochemistry of a petagram inventory. Science 354, 456-459.

Kujawinski, E.B., Hatcher, P.G., Freitas, M.A., 2002. High-resolution fourier transform ion cyclotron resonance mass spectrometry of humic and fulvic acids: improvements and comparisons. Anal. Chem. 74, 413-419.

Lechtenfeld, O.J., Kattner, G., Flerus, R., McCallister, S.L., Schmitt-Kopplin, P., Koch, B.P., 2014. Molecular transformation and degradation of refractory dissolved organic matter in the Atlantic and Southern Ocean. Geochim. Cosmochim. Acta 126, $321-337$.

Lefebvre, K.A., Silver, M.W., Coale, S.L., Tjeerdema, R.S., 2002. Domoic acid in planktivorous fish in relation to toxic Pseudo-nitzschia cell densities. Mar. Biol. 140, 625-631.

Lema, K.A., Latimier, M., Nézan, É., Fauchot, J., Le Gac, M., 2017. Inter and intra-specific growth and domoic acid production in relation to nutrient ratios and concentrations in Pseudo-nitzschia: phosphate an important factor. Harmful Algae 64, 11-19.

Li, Y., Harir, M., Uhl, J., Kanawati, B., Lucio, M., Smirnov, K.S., Koch, B.P., SchmittKopplin, P., Hertkorn, N., 2017. How representative are dissolved organic matter (DOM) extracts? A comprehensive study of sorbent selectivity for DOM isolation. Water Res. 116, 316-323.

Liu, H., Kelly, M.S., Campbell, D.A., Dong, S.L., Zhu, J.X., Wang, S.F., 2007. Exposure to domoic acid affects larval development of king scallop Pecten maximus (Linnaeus, 1758). Aquat. Toxicol. 81, 152-158.

Louchouam, P., Opsahl, S., Benner, R., 2000. Isolation and quantification of dissolved lignin from natural waters using solid-phase extraction and GC/MS. Anal. Chem. 72 2780-2787.

Ludwig, W., Probst, J.-L., Kempe, S., 1996. Predicting the oceanic input of organic carbon by continental erosion. Glob. Biogeochem. Cycles 10, 23-41.

Maldonado, M.T., Hughes, M.P., Rue, E.L., Wells, M.L., 2002. The effect of Fe and $\mathrm{Cu}$ on growth and domoic acid production by Pseudo-nitzschia multiseries and Pseudo-nitzschia australis. Limnol. Oceanogr. 47, 515-526.

Malviya, S., Scalco, E., Audic, S., Vincent, F., Veluchamy, A., Poulain, J., Wincker, P., Iudicone, D., de Vargas, C., Bittner, L., Zingone, A., Bowler, C., 2016. Insights into global diatom distribution and diversity in the world's ocean. Proc. Natl. Acad. Sci. 113, E1516-E1525.

Martin, J.L., Haya, K., Burridge, L.E., Wildish, D.J., 1990. Nitzschia pseudodelicatissima - a source of domoic acid in the Bay of Fundy, eastern Canada. Mar. Ecol. Prog. Ser. 67, $177-182$.

McCabe, R.M., Hickey, B.M., Kudela, R.M., Lefebvre, K.A., Adams, N.G., Bill, B.D., Gulland, F.M.D., Thomson, R.E., Cochlan, W.P., Trainer, V.L., 2016. An unprecedented coastwide toxic algal bloom linked to anomalous ocean conditions. Geophys. Res. Lett. 43, 10,366-10,376.

Møller, E.F., Thor, P., Nielsen, T.G., 2003. Production of DOC by Calanus finmarchicus, C. glacialis and C. hyperboreus through sloppy feeding and leakage from fecal pellets. Mar. Ecol. Prog. Ser. 262, 185-191.

Pan, Y., Parsons, M.L., Busman, M., Moeller, P.D.R., Dortch, Q., Powell, C.L., Doucette, G.J., 2001. Pseudo-nitzschia sp. cf. pseudodelicatissima - a confirmed producer of domoic acid from the northern Gulf of Mexico. Mar. Ecol. Prog. Ser. 220, 83-92.

Piletska, E.V., Villoslada, F.N., Chianella, I., Bossi, A., Karim, K., Whitcombe, M.J., Piletsky, S.A., Doucette, G.J., Ramsdell, J.S., 2008. Extraction of domoic acid from seawater and urine using a resin based on 2-(trifluoromethyl)acrylic acid. Anal. Chim. Acta 610, 35-43.

Pitcher, G.C., Cembella, A.D., Krock, B., Macey, B.M., Mansfield, L., Probyn, T.A., 2014 Identification of the marine diatom Pseudo-nitzschia multiseries (Bacillariophyceae) as a source of the toxin domoic acid in Algoa Bay, South Africa. African J. Mar. Sci. 36, $523-528$.

Pocklington, R., Milley, J.E., Bates, S.S., Bird, C.J., de Freitas, A.S.W., Quilliam, M.A., 1990. Trace determination of domoic acid in seawater and phytoplankton by highperformance liquid chromatography of the fluorenylmethoxycarbonyl (FMOC) derivative. Int. J. Environ. Anal. Chem. 38, 351-368.

Prince, E.K., Irmer, F., Pohnert, G., 2013. Domoic acid improves the competitive ability of pseudo-nitzschia delicatissima against the diatom skeletonema marinoi. Mar. Drugs 11, 2398-2412.

Quilliam, M.A., Wright, J.L.C., 1989. The amnesic shellfish poisoning mystery. Anal 
Chem. 61, 1053A-1060A

Rhodes, L., White, D., Shyre, M., Atkinson, M., 1996. Pseudo-nitzschia species isolated from New Zealand coastal waters: domoic acid production in vitro and links with shellfish toxicity. In: Yasumoto, T., Oshima, Y., Fukuyo, M. (Eds.), Harmful and Toxic Algal Blooms. Intergovernmental Oceanographic Commission of UNESCO, Paris, pp. 155-158.

Rhodes, L., Jiang, W., Knight, J., Adamson, K., Smith, V., Langi, V., Edgar, M., 2013. The genus Pseudo-nitzschia (Bacillariophyceae) in New Zealand: analysis of the last decade's monitoring data. N. Z. J. Mar. Freshw. Res. 47, 490-503.

Rue, E., Bruland, K., 2001. Domoic acid binds iron and copper: a possible role for the toxin produced by the marine diatom Pseudo-nitzschia. Mar. Chem. 76, 127-134.

Scharek, R., Tupas, L.M., Karl, D.M., 1999. Diatom fluxes to the deep sea in the oligotrophic North Pacific gyre at Station ALOHA. Mar. Ecol. Prog. Ser. 182, 55-67.

Scholin, C.A., Gulland, F., Doucette, G.J., Benson, S., Busman, M., Chavez, F.P., Cordaro, J., DeLong, R., De Vogelaere, A., Harvey, J., Haulena, M., Lefebvre, K.A., Lipscomb, T., Loscutoff, S., Lowenstine, L.J., Marin, R., Miller, P.E., McLellan, W.A., Moeller, P.D.R., Powell, C.L., Rowles, T., Silvagni, P., Silver, M., Spraker, T., Trainer, V., Van Dolah, F.M., 2000. Mortality of sea lions along the central California coast linked to a toxic diatom bloom. Nature 403, 80-84.

Sekula-Wood, E., Schnetzer, A., Benitez-Nelson, C.R., Anderson, C., Berelson, W.M., Brzezinski, M.A., Burns, J.M., Caron, D.A., Cetinic, I., Ferry, J.L., Fitzpatrick, E., Jones, B.H., Miller, P.E., Morton, S.L., Schaffner, R.A., Siegel, D.A., Thunell, R., 2009. Rapid downward transport of the neurotoxin domoic acid in coastal waters. Nat. Geosci. 2, 272-275.

Silver, M.W., Bargu, S., Coale, S.L., Benitez-Nelson, C.R., Garcia, A.C., Roberts, K.J., Sekula-Wood, E., Bruland, K.W., Coale, K.H., 2010. Toxic diatoms and domoic acid in natural and iron enriched waters of the oceanic Pacific. Proc. Natl. Acad. Sci. 107, 20762-20767.

Skrabal, S.A., Donat, J.R., Burdige, D.J., 2000. Pore water distributions of dissolved copper and copper-complexing ligands in estuarine and coastal marine sediments. Geochim. Cosmochim. Acta 64, 1843-1857.

Smith, J.C., Odense, P., Angus, R., Bates, S.S., Bird, C.J., Cormier, P., de Freitas, A.S.W., Léger, C., O'Neil, D., Pauley, K., Worms, J., 1990. Variation in domoic acid levels in Nitzschia species: implications for monitoring programs. Bull. Aquac. Assoc. Can. 90, $27-31$.

Smith, J., Gellene, A.G., Hubbard, K.A., Bowers, H.A., Kudela, R.M., Hayashi, K., Caron, D.A., 2018. Pseudo-nitzschia species composition varies concurrently with domoic acid concentrations during two different bloom events in the Southern California bight. J. Plankton Res. 40, 1-17.

Stenson, A.C., Landing, W.M., Marshall, A.G., Cooper, W.T., 2002. Ionization and fragmentation of humic substances in electrospray ionization Fourier transform-ion cyclotron resonance mass spectrometry. Anal. Chem. 74, 4397-4409.

Stenson, A.C., Marshall, A.G., Cooper, W.T., 2003. Exact masses and chemical formulas of individual Suwannee River fulvic acids from ultrahigh resolution electrospray ionization Fourier transform ion cyclotron resonance mass spectra. Anal. Chem. 75, 1275-1284.

Stewart, J.E., Marks, L.J., Gilgan, M.W., Pfeiffer, E., Zwicker, B.M., 1998. Microbial utilization of the neurotoxin domoic acid: blue mussels (Mytilus edulis) and soft shell clams (Mya arenaria) as sources of the microorganisms. Can. J. Microbiol. 44, 456-464.

Subba Rao, D.V., Quilliam, M.A., Pocklington, R., 1988. Domoic acid - a neurotoxic amino acid produced by the marine diatom Nitzschia pungens in culture. Can. J. Fish. Aquat. Sci. 45, 2076-2079.

Takemoto, T., Daigo, K., 1958. Constituents of Chondria armata. Chem. Pharm. Bull. 6,
$578-580$.

Tammilehto, A., Nielsen, T.G., Krock, B., Møller, E.F., Lundholm, N., 2012. Calanus spp vectors for the biotoxin, domoic acid, in the Arctic marine ecosystem? Harmful Algae $20,165-174$.

Tammilehto, A., Nielsen, T.G., Krock, B., Møller, E.F., Lundholm, N., 2015. Induction of domoic acid production in the toxic diatom Pseudo-nitzschia seriata by calanoid copepods. Aquat. Toxicol. 159, 52-61.

Taylor, B.B., Torrecilla, E., Bernhardt, A., Taylor, M.H., Peeken, I., Röttgers, R., Piera, J., Bracher, A., 2011. Bio-optical provinces in the eastern Atlantic Ocean and their biogeographical relevance. Biogeosciences 8, 3609-3629.

Trainer, V.L., Adams, N.G., Bill, B.D., Anulacion, B.F., Wekell, J.C., 1998. Concentration and dispersal of a Pseudo-nitzschia bloom in Penn Cove, Washington, USA. Nat. Toxins 6, 113-126.

Trainer, V.L., Adams, N.G., Bill, B.D., Stehr, C.M., Wekell, J.C., Moeller, P., Busman, M., Woodruff, D., 2000. Domoic acid production near California coastal upwelling zones, June (1998). Limnol. Oceanogr. 45, 1818-1833.

Trainer, V.L., Wells, M.L., Cochlan, W.P., Trick, C.G., Bill, B.D., Batgh, K.A., Beall, B.F., Herndon, J., Lundholm, N., 2009. An ecological study of a massive bloom of toxigenic Pseudo-nitzschia cuspidata off the Washington State coast. Limnol. Oceanogr. 54, 1461-1474.

Trainer, V.L., Bates, S.S., Lundholm, N., Thessen, A.E., Cochlan, W.P., Adams, N.G., Trick, C.G., 2012. Pseudo-nitzschia physiological ecology, phylogeny, toxicity, monitoring and impacts on ecosystem health. Harmful Algae 14, 271-300.

Trick, C.G., Bill, B.D., Cochlan, W.P., Wells, M.L., Trainer, V.L., Pickell, L.D., 2010. Iron enrichment stimulates toxic diatom production in high-nitrate, low-chlorophyll areas. Proc. Natl. Acad. Sci. 107, 5887-5892.

Trick, C.G., Trainer, V.L., Cochlan, W.P., Wells, M.L., Beall, B.F., 2018. The successional formation and release of domoic acid in a Pseudo-nitzschia bloom in the Juan de Fuca Eddy: a drifter study. Harmful Algae 79, 105-114.

Umhau, B.P., Benitez-Nelson, C.R., Anderson, C.R., McCabe, K., Burrell, C., 2018. A time series of water column distributions and sinking particle flux of Pseudo-Nitzschia and domoic acid in the Santa Barbara Basin, California. Toxins 10, 480.

Van Meerssche, E., Pinckney, J.L., 2017. The influence of salinity in the domoic acid effect on estuarine phytoplankton communities. Harmful Algae 69, 65-74.

Walter, J.A., Leek, D.M., Falk, M., 1992. NMR study of the protonation of domoic acid. Can. J. Chem. 70, 1156-1161.

Wang, Z., King, K.L., Ramsdell, J.S., Doucette, G.J., 2007. Determination of domoic acid in seawater and phytoplankton by liquid chromatography-tandem mass spectrometry. J. Chromatogr. A 1163, 169-176.

Wekell, J.C., Gauglitz, E.J., Bamett, H.J., Hatfield, C.L., Simons, D., Ayres, D., 1994 Occurrence of domoic acid in Washington State razor clams (Siliqua patula) during 1991-1993. Nat. Toxins 2, 197-205.

Wells, M.L., Trick, C.G., Cochlan, W.P., Hughes, M.P., Trainer, V.L., 2005. Domoic acid: the synergy of iron, copper, and the toxicity of diatoms. Limnol. Oceanogr. 50, 1908-1917.

Wright, J.L.C., Boyd, R.K., de Freitas, A.S.W., Falk, M., Foxall, R.A., Jamieson, W.D., Laycock, M.V., McCulloch, A.W., McInnes, A.G., Odense, P., Pathak, V.P., Quilliam, M.A., Ragan, M.A., Sim, P.G., Thibault, P., Walter, J.A., Gilgan, M., Richard, D.J.A., Dewar, D., 1989. Identification of domoic acid, a neuroexcitatory amino acid, in toxic mussels from eastern Prince Edward Island. Can. J. Chem. 67, 481-490.

Zhang, W., Lin, M., Tong, P., Lu, Q., Zhang, L., 2016. Ferrite nanospheres-based magnetic solid-phase extraction for determination of domoic acid in seawater samples using high-performance liquid chromatography with tandem mass spectrometry. J. Chromatogr. A 1443, 54-61. 